\title{
Naungan dan Tipe Substrat Berbeda pada Periode Aklimatisasi Ex-vitro Phalaenopsis Hibrid
}

\section{Shade and Different Substrate Types of Phalaenopsis Hybrid Ex-vitro Acclimatization Period}

\author{
Ade Arisma Fauziah ${ }^{1}$, Nurullita Prahasti ${ }^{1}$, Nintya Setiari ${ }^{2}$, Endang Saptiningsih ${ }^{2 *}$ \\ ${ }^{1}$ Program Studi Biologi, Departemen Biologi, Fakultas Sains dan Matematika, Universitas Diponegoro \\ ${ }^{2}$ Departemen Biologi Fakultas Sains dan Matematika Universitas Diponegoro \\ *Email: saptiningsihe@yahoo.co.id
}

Diterima 11 November 2019 / Disetujui 5 Maret 2020

\begin{abstract}
ABSTRAK
Produksi bibit Phalaenopsis Hibrid umumnya dilakukan melalui teknik kultur jaringan. Tahap selanjutnya adalah aklimatisasi plantlet di lingkungan ex-vitro. Penggunaan naungan dan tipe substrat berperan terhadap pertumbuhan dan kelangsungan hidup plantlet selama periode awal aklimatisasi. Penelitian ini mengkaji peran naungan dan tipe substrat yang berbeda terhadap pertumbuhan dan kelangsungan hidup plantlet Phalaenopsis Hibrid selama periode awal aklimatisasi di greenhouse. Penelitian menggunakan plantlet Phalaenopsis Hibrid dalam botol dan naungan paranet. Plantlet diberi 3 tipe substrat yaitu serabut kelapa, akar paku kadaka, sphagnum serta semua perlakuan dinaungi paranet secara bertahap. Parameter penelitian yang diukur meliputi: jumlah akar, total panjang akar, panjang daun, berat segar dan persentase kematian plantlet. Rancangan Acak Lengkap dengan satu faktor dan 3 ulangan digunakan dalam penelitian ini. Data dianalisis menggunakan ANOVA dan uji LSD pada taraf signifikansi 95\% ( $>0,05)$. Penelitian dilakukan selama 5 minggu di greenhouse Jurusan Biologi, Fakultas Sains dan Matemetika, UNDIP. Plantlet tumbuh dan mampu bertahan hidup pada semua substrat dan naungan paranet secara bertahap. Pembentukan pori besar pada substrat serabut kelapa dan akar kadaka meningkatkan jumlah dan panjang akar. Kemampuan menjerap air tinggi pada spagnum meningkatkan berat segar plantlet. Penutupan paranet secara bertahap dan penggunaan substrat serabut kelapa, akar kadaka serta spagnum mempertahankan kelangsungan hidup plantlet selama periode awal aklimatisasi ex-vitro.
\end{abstract}

Kata kunci:aklimatisasi, Phalaenopsis Hibrid, serabut kelapa, akar kadaka, sphagnum

\begin{abstract}
Production of Phalaenopsis hybrid was carried out generally by tissue culture techniques. The next step was the acclimatization of plantlets in an ex-vitro environment. Used of shade and substrate types contributed to the growth and survival of plantlets during the initial acclimatization period. The research aimed to examine the role of shade and different substrate types on the growth and survival of Phalaenopsis Hybrid plantlets during the initial period of ex-vitro acclimatization. The study used plantlets of Phalaenopsis Hybrid in bottles and paranet shade. Plantlets were treated by 3 substrate type, namely coconut fibers, kadaka fern roots, and sphagnum. All treatments were gradually shaded with paranet nets. A Completely Randomized Design with one factor and 3 replications was used in this study. Data were analyzed using ANOVA and LSD test at a significance level of $95 \%$ ( $\mathrm{P}<0.05$ ). The study was conducted for 5 weeks in the greenhouse of the Department of Biology, Faculty of Science and Mathematics, UNDIP. Plantlets grew and were able to survive on all substrates and shade gradually. The formation of large pores on the substrate of coconut fibers and kadaka fern roots could increase the number and length of roots. The ability to absorb water that was high in sphagnum could increase the fresh weight of plantlets. Paranet closure gradually and used substrate of coconut fibers, kadaka fern roots and, sphagnum maintain plantlets survival during the initial period of ex-vitro acclimatization.
\end{abstract}

Keywords: acclimatization, Phalaenopsis Hybrid, coconut fiber, kadaka fern root, sphagnum 


\section{PENDAHULUAN}

Phalaenopsis adalah salah satu genus tanaman anggrek yang banyak diminati (Cha-um et al., 2010). Terdapat sekitar 60 spesies dari genus Phalaenopsis yang tersebar di Asia dan Samudera Pasifik meliputi Sri Lanka, India Selatan, Papua Nugini, Cina Selatan, Taiwan, dan Filipina Utara (Yuan et al., 2018). Phalaenopsis berasal dari daerah beriklim sedang yang memiliki suhu rendah $\left(\leq 25^{\circ} \mathrm{C}\right)$ sehingga suhu tinggi merupakan kondisi cekaman terutama untuk Phalaenopsis Hibrid (Cha-um et al., 2010). Secara konvensional, perbanyakan anggrek dilakukan dengan pemisahan umbi atau stek vegetatif yang hanya menghasilkan beberapa propagul dalam satu tahun (Venturieri dan Pickscius, 2013). Produksi tanaman anggrek yang mempunyai kesamaan genetik dalam jumlah besar dan plantlet berkualitas tinggi secara fisiologis dan fitosanitari dalam waktu singkat dilakukan dengan teknik kultur jaringan (da Silva et al., 2017).

Salah satu tahapan penting dalam mikropropagasi dengan teknik kultur jaringan adalah tahapan aklimatisasi (Cha-um et al., 2010). Kondisi lingkungan dalam kultur in-vitro merupakan lingkungan yang aseptik, ketersediaan nutrien tinggi, intensitas cahaya, konsentrasi $\mathrm{CO} 2$, perubahan temperatur dan kelembaban udara yang rendah (da Silva et al., 2017). Kondisi tersebut menghasilkan plantlet yang heterotrof atau photomixotrophic dengan karakter morfologis, anatomis dan fisiologis tertentu. Sementara kondisi lingkungan ex-vitro meliputi lingkungan dengan intensitas cahaya, konsentrasi $\mathrm{CO}$, perubahan temperatur dan kelembaban udara yang tinggi (Shin et al., 2014). Periode aklimatisasi berperan penting dalam mengkondisikan plantlet untuk beradaptasi menuju lingkungan ex-vitro (Chandra et al., 2010). Tahap aklimatisasi berhubungan erat dengan persentase kelangsungan hidup, pertumbuhan dan perkembangan plantlet.

Perkembangan perakaran, pertumbuhan daun dan kelangsungan hidup merupakan faktor penting keberhasilan plantlet selama aklimatisasi (da Silva et al., 2017). Perubahan karakter heterotrof ke autotrof ditandai dengan keberhasilan plantlet dalam penyerapan air dan hara oleh akar serta pengaturan transpirasi dan fotosintesis di daun. Salah satu upaya dalam mendukung adaptasi plantlet di lingkungan exvitro adalah penentuan tipe substrat, pengaturan intensitas cahaya serta temperatur udara dengan penggunaan paranet atau naungan (Venturieri dan de Arbieto, 2011). Substrat berperan dalam ketersediaan air, hara, tingkat keasaman dan udara yang mendukung pertumbuhan sistem perakaran. Sementara pengaturan intensitas cahaya dan temperatur udara berhubungan erat dengan proses transpirasi dan fotosintesis untuk pertumbuhan plantlet.

Penggunaan campuran substrat gambut, pasir gurun dan perlit dilaporkan meningkatkan kelangsungan hidup plantlet Dendrobium nobile cv. sebesar 100\% (Mirani et al., 2017). Campuran substrat tersebut mampu menyerap air tinggi dengan porositas dan aerasi sedang serta tingkat kontaminasi rendah. Di Brazil, substrat terbaik untuk aklimatisasi anggrek adalah xaxim namun penggunaan xaxim telah dilarang sejak tahun 2001 karena mengakibatkan kerusakan hutan (Seidel Júnior dan Venturieri, 2011). Dilaporkan beberapa substrat seperti gambut, akar pakis, kompos dan vermikulit digunakan untuk substrat aklimatisasi beberapa anggrek seperti Phalaenopsis amabilis, Cattleya forbesii dan Laelia purpurata terkait kemampuannya dalam mendukung pertumbuhan plantlet (Seidel Júnior dan Venturieri, 2011; Venturieri dan de Arbieto, 2011). da Silva et al. (2017) juga melaporkan penggunaan teknik naungan dalam mengatur intensitas cahaya dan kelembaban udara selama periode aklimatisasi anggrek. Sorgato et al. (2015), menyatakan bahwa pengaturan intensitas cahaya selama periode aklimatisasi sangat menentukan tingkat keberhasilan hidup plantlet anggrek. Indonesia kaya akan sumber daya alam dengan kemelimpahan substrat untuk pertumbuhan anggrek seperti moss sphagnum, serabut kelapa dan akar paku kadaka (Asplenium sp). Karakteristik substrat-substrat tersebut dan pengaruhnya terhadap pertumbuhan plantlet anggrek belum banyak diteliti. Penelitian ini bertujuan mengkaji tipe substrat yaitu serabut 
kelapa, akar kadaka dan sphagnum serta penggunaan paranet dalam mendukung pertumbuhan dan ketahanan plantlet Phalaenopsis Hibrid selama periode aklimatisasi ex-vitro.

\section{METODE PENELITIAN}

Bahan penelitian adalah plantlet Phalaenopsis Hibrid umur 6 bulan yang berasal dari Kebun Anggrek "Green Leaves Orchid", Salatiga, Jawa Tengah. Subtrat pertumbuhan plantlet terdiri dari serabut kelapa, akar kadaka dan sphagnum. Pemberian naungan menggunakan paranet ukuran $60 \%$. Penelitian berlangsung selama 5 minggu dan dilaksanakan di greenhouse Departemen Biologi, Fakultas Sains dan Matematika, Universitas Diponegoro.

Plantlet dikeluarkan dari botol kultur kemudian dibersihkan dari sisa-sisa media. Selanjutnya plantlet direndam dalam larutan fungisida dengan konsentrasi $3 \mathrm{~g} / \mathrm{L}$ selama 15 menit. Plantlet ditiriskan di atas kertas merang dan dilakukan pengukuran parameter penelitian awal pada minggu ke-0. Parameter penelitian meliputi jumlah akar, total panjang akar, panjang daun (daun ke-1, ke-2 dan ke-3) dan berat segar plantlet. Jumlah akar ditentukan berdasarkan jumlah akar seluruhnya per tanaman. Total panjang akar ditentukan dengan mengukur panjang keseluruhan akar per tanaman. Panjang daun diukur dari pangkal helaian daun sampai ujung daun menggunakan penggaris dan berat segar plantlet diukur menggunakan timbangan digital merk Camry kapasitas $200 \mathrm{~g}$. Kelangsungan hidup plantlet ditentukan secara visual dan dihitung berdasarkan persentase plantlet mati yang diukur pada minggu ke-5. Masing-masing tipe substrat kemudian dibersihkan dan direndam dalam fungisida. Selanjutnya substrat ditempatkan pada wadah plastik berongga dengan ukuran 15 × 25 x 8 ( $\mathrm{p}$ x 1 $\mathrm{x} t)$. Sebanyak 15 plantlet yang besarnya seragam ditanam pada masing-masing tipe substrat, kemudian dimasukkan ke dalam kotak kaca berukuran $60 \times 50 \times 40(\mathrm{p} \times 1 \times \mathrm{t})$ dan ditutup dengan paranet secara bertahap. Penutupan paranet penuh dilakukan pada minggu ke-1 dan minggu ke-2, paranet dibuka sebagian pada minggu ke-3 dan ke-4 dan paranet dibuka seluruhnya atau tanpa naungan pada minggu ke-5. Pengukuran parameter penelitian juga dilakukan pada minggu ke-4 dan minggu ke-5.

Penelitian menggunakan Rancangan Acak Lengkap (RAL) satu faktor yaitu tipe substrat. Tipe substrat meliputi: serabut kelapa, akar kadaka dan sphagnum. Data pada masing-masing parameter dianalisis dengan ANOVA, apabila terdapat perbedaan pengaruh yang signifikan maka dilanjutkan dengan Uji LSD pada taraf signifikansi 95\% (P< 0,05). Seluruh analisis dilakukan dengan program SPSS 16.0 dan Excell 2010 for Windows.

\section{HASIL DAN PEMBAHASAN}

Pertumbuhan akar meliputi variabel jumlah dan panjang akar mengalami pola peningkatan pada substrat serabut kelapa dan akar kadaka, sementara pada substrat spagnum mengalami penurunan (Gambar 1). Jumlah dan panjang akar tertinggi secara signifikan $(\mathrm{P}<0,05)$ terdapat pada substrat serabut kelapa dan akar kadaka selama periode aklimatisasi 5 minggu (Gambar 1).

Perubahan lingkungan mikro terjadi pada plantlet dari kondisi in-vitro ke kondisi ex-vitro. Plantlet selama kultur in-vitro tumbuh pada media padat yang steril dengan kelembaban tinggi, ketersediaan sumber energi (heterotrof), pencahayaan dan temperatur yang optimal (Virag et al., 2011). Di dalam lingkungan ex-vitro, plantlet terpapar kondisi yang tidak steril dengan perubahan ketersediaan hara, kelembaban, cahaya dan temperatur (Chandra et al., 2010). Karakter plantlet berubah dari heterotrof menjadi autotrof (Diaz et al., 2010). Karakter fotoautotrof membutuhkan peran akar dalam penyerapan air dan unsur hara serta organ daun dalam menunjang proses transpirasi, difusi gas $\left(\mathrm{O}_{2}\right.$ dan $\left.\mathrm{CO}_{2}\right)$ dan fotosintesis (Diaz et al., 2010; Shin et al., 2014). Substrat pertumbuhan anggrek selama periode aklimatisasi berperan penting dalam mendukung karakter fotoautotrof. Pertumbuhan akar dipengaruhi oleh kondisi substrat meliputi aerasi, permeabilitas, $\mathrm{pH}$, kelembaban dan ketahanan terhadap pelapukan (Diaz et al., 2010; da Silva et al., 2017). Masing-masing substrat yaitu serabut 
kelapa, akar kadaka dan sphagnum memiliki karakteristik terkait pembentukan pori, aerasi dan penjerapan air. Serabut kelapa mempunyai karakter yang hampir sama dengan akar kadaka. Kedua substrat tersebut membentuk ruang pori yang longgar sehingga mempunyai aerasi dan tingkat permeabilitas yang tinggi namun kurang kemampuannya dalam menjerap air (Trimanto dan Rahadiantoro, 2017; Ritzinger et al., 2018). Kondisi tersebut mendukung ketersediaan $\mathrm{O}_{2}$ bagi akar. Oksigen dibutuhkan dalam proses respirasi untuk menghasilkan ATP, selanjutnya ATP digunakan untuk pertumbuhan akar. Hasil penelitian ini didukung oleh penelitian-penelitian yang telah dilakukan sebelumnya. Penggunaan serabut kelapa untuk pertumbuhan akar telah dilaporkan pada semai Malpighia emarginata Sessé \& Moc. ex DC (Ritzinger et al., 2018).
Penggunaan serabut kelapa sebagai campuran media semai tersebut mampu meningkatkan retensi air dan porositas sehingga mendukung pertumbuhan akar. Dilaporkan juga penggunaan akar kadaka pada aklimatisasi anggrek Dendrobium sp (Trimanto, 2013). Akar kadaka mampu menahan air dan unsur hara sehingga meningkatkan panjang akar sebesar 41, 63\% (Tirta, 2006; Trimanto, 2013). Hal sebaliknya terjadi pada sphagnum, kemampuan menjerap air tinggi namun tingkat aerasi dan permeabilitas terhadap air rendah sehingga mengakibatkan pertumbuhan akar lebih rendah. Seidel Júnior dan Venturieri (2011), melaporkan terjadi penurunan kelangsungan hidup semai Cattleya forbesii dan Laelia purpurata dalam substrat sphagnum selama aklimatisasi.
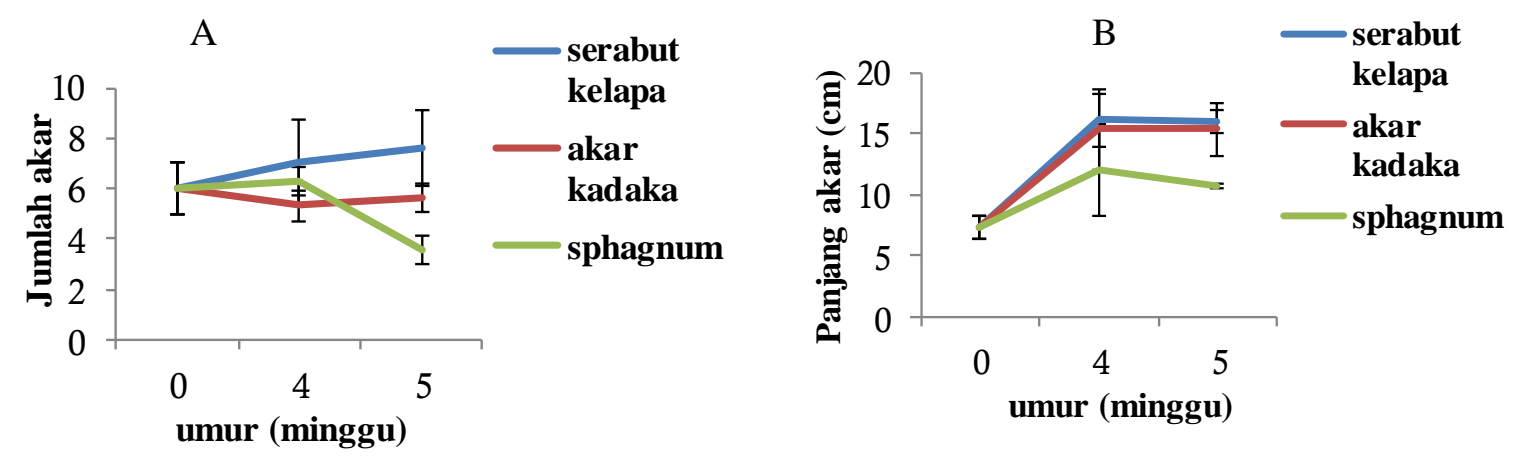

Gambar 1. Pertumbuhan akar Phalaenopsis Hibrid pada tipe substrat yang berbeda selama aklimatisasi exvitro. A). Jumlah akar dan B). Panjang akar. Plantlet memasuki periode aklimatisasi ex-vitro setelah dikultur in-vitro selama 6 bulan. Garis bar menunjukkan mean \pm SD $(n=3)$.

Pertumbuhan daun ke-1 menunjukkan pola penurunan pada semua tipe substrat, namun terjadi pola peningkatan panjang daun ke-2 pada substrat sphagnum (Gambar 2). Pertumbuhan daun ke-3 pada substrat sphagnum mengalami peningkatan selama penutupan paranet penuh hingga paranet dibuka sebagian (umur 0-4 minggu), sedangkan pembukaan paranet seluruhnya (umur 4-5 minggu) mengakibatkan penurunan panjang daun (Gambar 2). Pola yang sebaliknya terjadi pada substrat serabut kelapa. Panjang daun ke-3 tidak menunjukkan perbedaan yang signifikan diantara ketiga substrat di akhir penelitian.
Terjadi pola penurunan pertumbuhan daun ke-1 karena daun ke-1 merupakan daun yang berkembang selama kultur in-vitro. Ciri-ciri daun tersebut yaitu: lamina daun tipis, stomata belum berfungsi dan kepadatan tinggi, kutikula atau lapisan lilin belum terbentuk serta mesofil belum terdiferensiasi (Chandra et al., 2010). Daun ke-1 umumnya mengalami kerusakan pada kondisi ex-vitro dan digantikan oleh daun lain yang tumbuh selama periode aklimatisasi (da Silva et al., 2017). Daun ke-2 merupakan daun yang belum berkembang sepenuhnya selama kultur in-vitro sehingga terjadi perkembangan lebih lanjut selama periode aklimatisasi. Nampaknya karakter penjerab air tinggi pada 
substrat sphagnum mendukung peningkatan perkembangan daun ke-2 selama periode aklimatisasi (Gambar 2). Perkembangan daun ke3 berlangsung sepenuhnya dalam kondisi ex-vitro. Tipe substrat serabut kelapa yaitu aerasi tinggi dan penjerapan air rendah kemungkinan mendukung adaptasi perkembangan awal daun ke-3. Pembukaan paranet penuh pada minggu ke5 tidak mengakibatkan cekaman abiotik pada pertumbuhan daun sehingga terjadi pola peningkatan pertumbuhan daun ke-3 di akhir

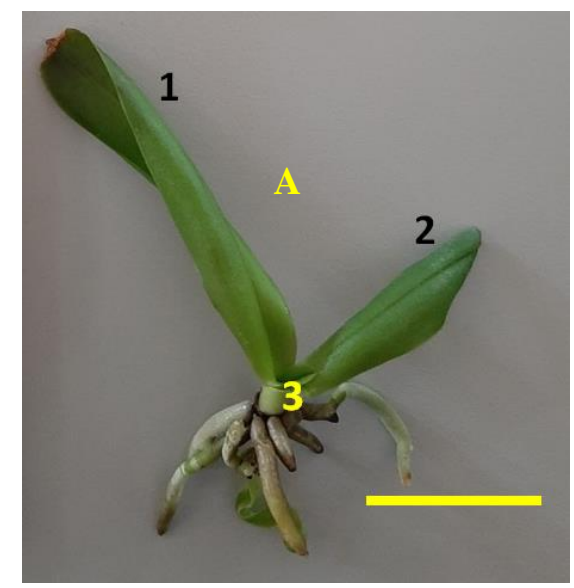

C

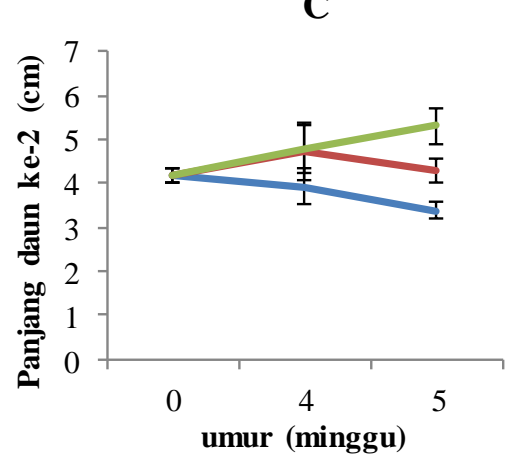

penelitian. Pada substrat spagnum dengan karakter penjerapan air tinggi hanya mendukung pertumbuhan daun ke-3 selama penutupan paranet. Pembukaan paranet pada minggu ke-5 mengakibatkan cekaman pada perkembangan awal daun ke-3 sehingga terjadi pola penurunan pertumbuhan. da Silva et al. (2017), melaporkan pada Dendrobium bahwa kurang berkembangnya struktur dan fungsi fisiologis daun mengakibatkan daun rentan terhadap perubahan lingkungan.
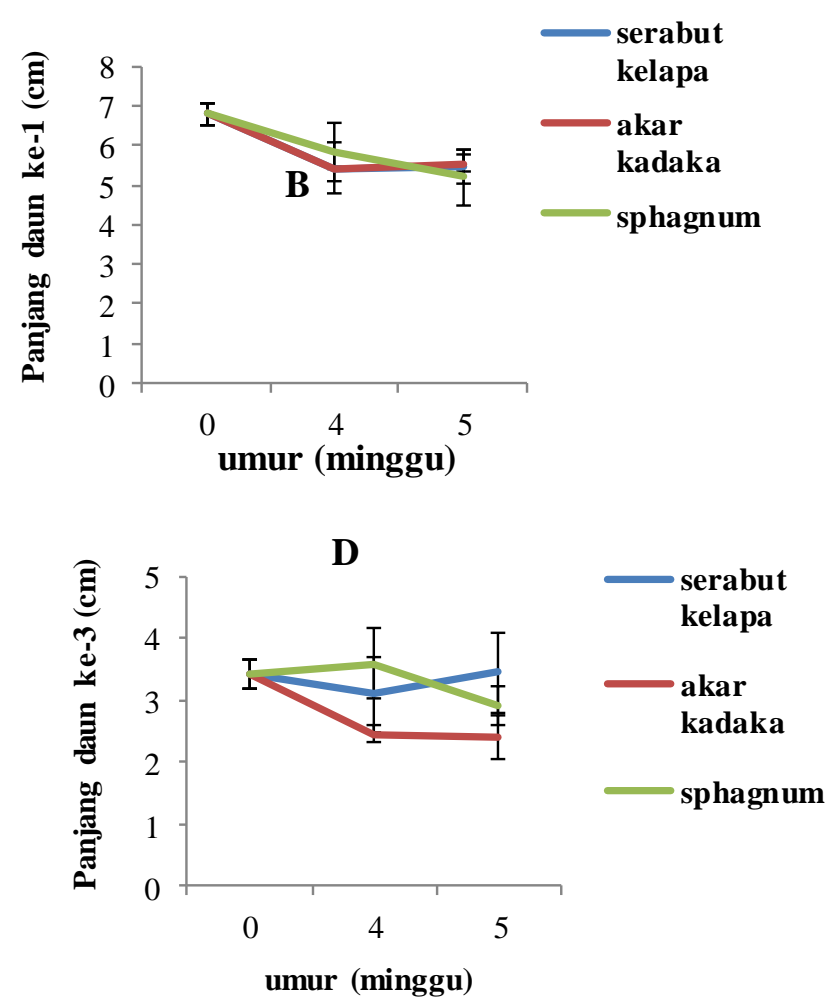

Gambar 2. Pertumbuhan daun Phalaenopsis Hibrid selama aklimatisasi ex-vitro 5 minggu. Morfologi daun ke1, ke-2 dan ke-3 (A), panjang daun ke-1 (B), panjang ke-2 (C) dan panjang daun ke-3 (D). Bar $=5$ $\mathrm{cm}(\mathrm{A})$ dan garis bar menunjukkan mean $\pm \mathrm{SD}(\mathrm{n}=3)$ pada gambar $\mathrm{B}, \mathrm{C}$ dan $\mathrm{D}$.

Berat segar plantlet pada tiap periode pengamatan (umur 0,4 dan 5 minggu) menunjukkan perbedaan yang tidak signifikan diantara tipe substrat, namun berat segar cenderung meningkat dibanding berat segar di awal periode aklimatisasi. Sementara kelangsungan hidup plantlet selama 5 minggu ditunjukkan oleh keberhasilan hidup $100 \%$ pada semua tipe substrat. Berat segar plantlet merupakan akumulasi fotosintat dan kandungan air (Wu dan Lin, 2013). Peningkatan berat segar plantlet pada semua tipe substrat menunjukkan telah berfungsinya peran akar dalam penyerapan air dan organ daun dalam proses transpirasi, difusi gas dan fotosintesis. Hal ini mendukung perkembangan karakter fotoautotrof plantlet. Shin et al. (2014), melaporkan peningkatan kemampuan fotoautotrof pada anggrek Doritaenopsis hibrid mempengaruhi kelangsungan hidup plantlet selama aklimatisasi. 
Perkembangan sistem perakaran, fungsi stomata dan kutikula pada plantlet Dendrobium juga dilaporkan meningkatkan kelangsungan hidup dalam kondisi ex-vitro (da Silva et al., 2017). Pada plantlet Phalaenopsis, peningkatan konduktivitas stomata dan laju fotosintesis (efisiensi dan kandungan pigmen fotosintesis) dilaporkan dapat meningkatkan kemampuan adaptasi plantlet pada kondisi ex-vitro (Cha-um et al., 2010).

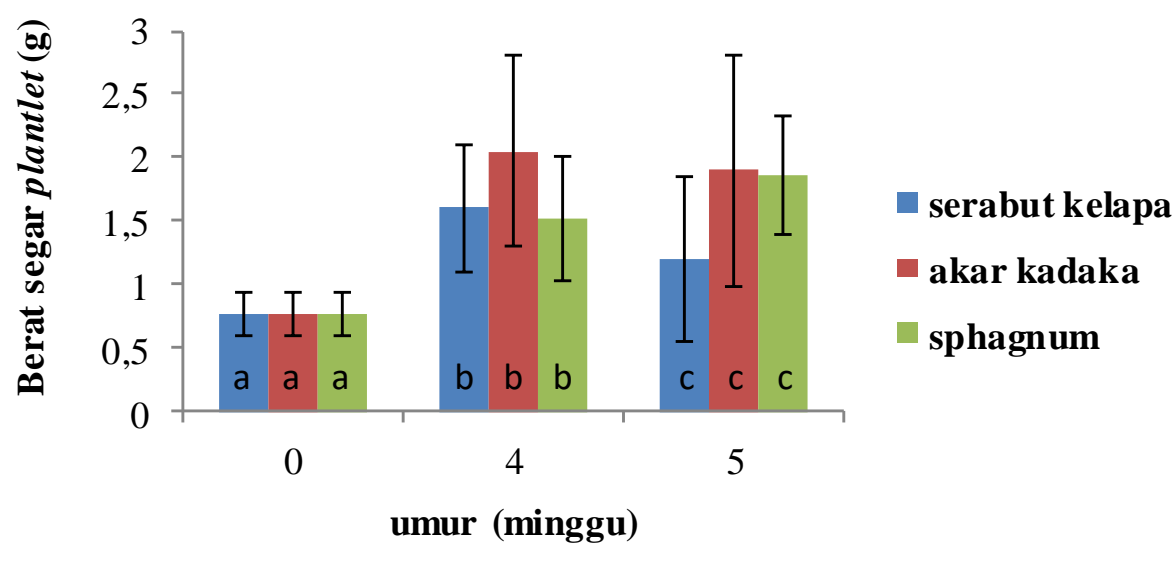

Gambar 3. Berat segar plantlet pada periode aklimatisasi ex-vitro selama 5 minggu. Bar yang diikuti oleh huruf yang sama menunjukkan perbedaan yang tidak signifikan $(P<0,05)$ dengan uji LSD $(n=3)$.

\section{KESIMPULAN}

Substrat serabut kelapa dan akar kadaka dapat meningkatkan sistem perakaran plantlet, sementara sphagnum mendukung ketersediaan air sehingga berat segar plantlet dapat ditingkatkan. Penggunaan naungan dan substrat serabut kelapa, akar kadaka dan sphagnum selama aklimatisasi $e x$ vitro meningkatkan kemampuan fotoautrotof plantlet Phalaenopsis Hibrid sehingga kelangsungan hidupnya dapat dipertahankan.

\section{DAFTAR PUSTAKA}

Chandra, S., Bandopadhyay, R., Kumar, V. dan Chandra, R. 2010. Acclimatization of tissue cultured plantlets: from laboratory to land. Biotechnology letters 32(9): 1199-1205.

Cha-um, S., Ulziibat, B. dan Kirdmanee, C. 2010. Effects of Temperature and Relative Humidity During in 'vitro' Acclimatization, on Physiological Changes and Growth Characters of' Phalaenopsis' Adapted to in'vivo'. Australian journal of crop science 4(9): 750.

da Silva, J. A. T., Hossain, M. M., Sharma, M., Dobránszki, J., Cardoso dan Songjun, Z.
2017. Acclimatization of in Vitro-derived Dendrobium. Horticultural Plant Journal 3(3): 110-124.

Díaz, L. P., Namur, J. J., Bollati, S. A. dan Arce, O. E. A. 2010. Acclimatization of Phalaenopsis and Cattleya obtained by micropropagation. Revista Colombiana de Biotecnología 12(2): 27-40.

Mirani, A. A., Abul-Soad, A. A. dan Markhand, G. S. 2017. Effect of different substrates on survival and growth of transplanted orchids (Dendrobium nobile cv.) into net house. Int J. Hortic. Floricult 5(4): 310-317.

Ritzinger, R., Ritzinger, C. H. S. P., Fonseca, N. dan Machado, C. D. F. 2018. Advances in the propagation of acerola. Revista Brasileira de Fruticultura 40(3): 1-12

Seidel Júnior, D. dan Venturieri, G. A. 2011. Ex vitro acclimatization of Cattleya forbesii and Laelia purpurata seedlings in a selection of substrates. Acta Scientiarum. Agronomy 33(1): 97-103.

Shin, K. S., Park, S. Y. dan Paek, K. Y. 2014. Physiological and biochemical changes during acclimatization in a Doritaenopsis 
hybrid cultivated in different microenvironments in vitro. Environmental and Experimental Botany 100: 26-33.

Sorgato, J. C., Rosa, Y. B. C. J., Soares, J. S., Lemes, C. S. R. dan Sousa, G. G. D. 2015. Light in intermediate acclimatization of in vitro germinated seedlings of Dendrobium phalaenopsis Deang Suree. Ciência Rural 45(2): 231-237.

Tirta, I.G. 2006. Pengaruh Beberapa Jenis Media Tanam dan Pupuk Daun terhadap Pertumbuhan Vegetatif Anggrek Jamrud (Dendrobium macrophyllum A. Rich.). Biodiversitas 7(1): 81-84.

Trimanto. 2013. Acclimatization of plant collection from East Nusa Tenggara exploration (Egon Forest, Mutis Mount and Camplong Park) at Purwodadi Botanic Garden. Journal of Biological Researches 19: 5-10.

Trimanto, T. dan Rahadiantoro, A. 2017. Acclimatization of plant collection from Moyo Island Forest, West Nusa Tenggara,

Indonesia at Purwodadi Botanic Garden. Tropical Drylands 1(1): 43-49.
Venturieri, G. A. \& Pickscius, F. J. 2013. Propagation of noble dendrobium (Dendrobium nobile Lindl.) by cutting. Acta Scientiarum. Agronomy 35(4): 501-504.

Venturieri, G. A. dan Arbieto, E. A. M. D. 2011. Ex-vitro establishment of Phalaenopsis amabilis seedlings in different substrates. Acta Scientiarum. Agronomy, 33(3): 495501.

Virág, E., Molnár, Z. dan Ördög, V. 2011. Application of algal biomass for enhanced acclimatization of orchids. Acta Biologica Szegediensis 55(1): 179-181.

Wu, H. C. dan Lin, C. C. 2013. Carbon dioxide enrichment during photoautotrophic micropropagation of Protea cynaroides L. plantlets improves in vitro growth, net photosynthetic rate, and acclimatization. HortScience 48(10): 1293-1297.

Yuan, S. C., Chin, S. W., Lee, C. Y. dan Chen, F. C. 2018. Phalaenopsis pollinia storage at subzero temperature and its pollen viability assessment. Botanical studies 59(1): 1. 